$\mathrm{Nr} 2(65), 2020$, s. 25-37

https://doi.org/10.12797/Politeja.17.2020.65.02

\title{
Irena SZLACHCICOWA
}

Uniwersytet Wrocławski

i.szlachcicowa@gmail.com

\section{CIERPIENIE I PAMIĘĆ - O TRANSMISJI DOŚWIADCZENIA W NARRACJI}

\section{ABSTRACT Suffering and Memory - on the Experience Transmission in the Narrative} The traumatic experience of war and the Holocaust not only left its mark on the psyche of the people affected by it, it also left a deep imprint on the consciousness of the next generation. The aim of this article is to present the phenomenon of generational transmission of post-war trauma in relation to the concept of trajectory, developed in sociology. The concept of trajectory allows for better examination and understanding of the biographical processes of suffering that arises and grows in the situation of social disorder and the breakdown of moral norms. Tragic experiences from the parents' past are a significant conditioning of the way children perceive their stories and themselves. Post-memory, as the second generation's memory created by family narratives, is a form of remembering what has happened, which determines the process of constructing the self.

Keywords: experience, narration, suffering, trajectory, identity, post-memory

Słowa kluczowe: doświadczenie, narracja, cierpienie, trajektoria, tożsamość, postpamięć 
$\mathrm{D}$ oświadczenia związane z traumą drugiej wojny światowej i Holokaustu są postrzegane jako głęboko naznaczające, mroczne i niedające się opisać. Odsyłają do fragmentu historii o wyjątkowym znaczeniu w wymiarze globalnym. Stanowią zaczyn i materię najważniejszych debat we współczesnym świecie, wyznaczają bogate spektrum zagadnień i prowokują do podejmowania trudnych kwestii. Problematyka Zagłady, szczególnie w ostatnich latach, budzi szerokie zainteresowanie zarówno opinii publicznej, jak i środowiska akademickiego. Wzrost zainteresowania tą problematyką przekłada się na obfitość i różnorodność publikowanych tekstów, zajmowanych stanowisk. Wszelka refleksja nad problemem Holokaustu dotyka fundamentalnych kwestii, których nie sposób uniknąć i które nie zawsze udaje się wyjaśnić. Trudność pisania o Holokauście - zdaniem Franka Ankersmita - związana jest z ryzykiem uwiktania się $w$ btędne koto nieporozumień i niemoralności ${ }^{1}$, którego udaje się uniknąć jedynie wówczas, gdy w rozważaniach przyjmujemy perspektywę estetyki. Wymaga to jednak świadomej rezygnacji z dążenia do poznania faktograficznej prawdy o rzeczywistości oraz odrzucenia kategorii etycznych.

\section{DOŚWIADCZENIE, PAMIĘĆ, NARRACJA}

Wieloznaczność i niedookreśloność kategorii „doświadczenie” wielokrotnie poddawano wnikliwej refleksji. Zaciekawienie doświadczeniem, przez jednych postrzegane jako ważne i zwiastujące kolejny zwrot w humanistyce, przez innych traktowane jako kłopotliwe i zbyteczne, jest faktem i stanowi teoretyczne wyzwanie ${ }^{2}$. Ożywienie zainteresowania tym pojęciem jest wiązane przede wszystkim z kryzysem scjentystycznego myślenia na gruncie humanistyki i nauk społecznych. Symbolizuje odchodzenie od statycznej wizji społecznego świata i zastąpienie jej procesualną koncepcją rzeczywistości. Zmiana myślenia prowadzi nie tyle do stawiania pytań o to, jaka jest rzeczywistość, ile do podejmowania prób pokazania, jak powstaje ład społeczny w wyniku dynamicznego oddziaływania jednostkowej subiektywności i obiektywnej rzeczywistości. Porzucenie strukturalno-funkcjonalnych schematów ujmowania rzeczywistości prowadzi do poszukiwania nowego instrumentarium pojęciowego i rozszerza pole badań.

Obraz rzeczywistości wyłania się z połączenia indywidualnych sposobów jej przeżywania, różnego rodzaju doświadczenia wypełniają ludzkie życie, nadając mu sens. Unikalność osobistych doświadczeń pozwala się zrozumieć jedynie poprzez ich odniesienie

F. Ankersmit, Narracja, reprezentacja, doświadczenie. Studia z teorii historiografii, red. i wstęp E. Domańska, Kraków 2004, s. 403.

2 Wyczerpujący przegląd teoretycznych perspektyw, w których podejmowana jest problematyka doświadczenia, przedstawia Dorota Wolska w pracy Odzyskać doświadczenie. Sporny temat humanistyki wspótczesnej, Kraków 2012. Zob. także: F. Ankersmit, Narracja, reprezentacja...; D. LaCapra, Historia w okresie przejściowym. Doświadczenie, tożsamość, teoria krytyczna, przeł. K. Bojarska, Kraków 2009; Doświadczenie, red. T. Buksiński, Poznań 2001; V. Turner, E.M. Bruner, Antropologia doświadczenia, przeł. E. Klekot, A. Szurek, Kraków 2011. 
do tego, co społecznie podzielane. Semiotyczny charakter rzeczywistości ukazuje powiązanie sfery społecznych działań z językiem. Ludzkie doświadczenia egzystencjalne, aby mogły stać się materiałem badawczym, muszą zostać osadzone w języku, przełożone nań. Opisu rzeczywistości społecznej dokonujemy bowiem za pomocą słów, przenosząc to, co przeżywane, w sferę języka ${ }^{3}$.

Doświadczenie stanowi prymarny wymiar ludzkiego funkcjonowania w świecie, przedstawianie go za pomocą słów jest zawsze względem tych doświadczeń wtórne. Stąd bierze swój początek odczucie, że tego, co przeżywane, nie da się wyrazić słowami, że zawsze istnieje swojego rodzaju nadmiar doświadczenia nad słowami, a język nie potrafi w pełni uchwycić sensu doświadczenia. Chociaż żyjemy wśród znaków i słów, i potrzebujemy słów, aby siebie i świat zrozumieć, istotą ludzkiej egzystencji jest jej przeżywanie ${ }^{4}$. Tworzywem świata są zdarzenia i ludzie, którzy je przeżywają, nie słowa. To, co przeżyte, może być kanwą opowiadania biograficznego, przetworzenia doświadczenia w narrację o sobie i świecie ${ }^{5}$. Narracja jest jedynie próbą uchwycenia tych przeżyć, mglistym, czasami wręcz nieporadnym ich odbiciem. Język jako instrument poznania rzeczywistości nie gwarantuje bezpośredniego do niej dostępu. Sprowadzenie sposobu doświadczania rzeczywistości do tekstu odsłania nieprzystawalność języka do świata. Doświadczenie nie daje się bowiem sprowadzić do słów, a ujmowanie go jedynie w tym wymiarze musi prowadzić do zredukowania istotnych jego aspektów. Język, mimo że nie daje nam bezpośredniego dostępu do rzeczywistości, pozostaje środkiem jej poznania i interpretacji. Procesy interpretacji rozumiane jako tworzenie i negocjowanie znaczeń zapośredniczają wszelkie formy ludzkiej egzystencji, jak również sposób jej poznania. Jakościowa dystynkcja pomiędzy światem rzeczy i światem słów jako nieusuwalna w swej istocie uświadamia umowność, ale i nieuchronność zabiegów interpretacyjnych.

Konceptualizacja doświadczenia wymaga wyraźnego odniesienia do pamięci ${ }^{6}$ jako medium łączącego przeszłość z teraźniejszością. Pojęcie doświadczenia odsyła bowiem do tego, co zdarza się teraz, będąc jednocześnie wspótczesna przesztością, której wydarzenia sa interioryzowane i które można sobie przypominać. Zarówno praca rozumu, jak i nieświadome sposoby zachowania, które nie stanowia albo już nie stanowia części naszej wiedzy, taczą się ze soba $w$ trakcie doświadczenia. Następnie w każdorazowo wtasnym

3 Por. K. Hastrup, Droga do antropologii. Między doświadczeniem a teoria, przeł. E. Klekot, Kraków 2008, s. 24; G. Badura, O obiektywności poznania socjologicznego raz jeszcze, Kraków 2015, s. 93-94.

$4 \quad$ K. Hastrup, Droga do antropologii..., s. 73.

5 P. Ricoeur, Drogi rozpoznania, przeł. J. Margański, Kraków 2004, s. 87.

6 Pamięć jako istotny atrybut jednostkowej i społecznej egzystencji od dawna jest przedmiotem zainteresowania wielu dyscyplin. W kontekście prowadzonych rozważań szczególne znaczenie należy przypisać badaniom z zakresu psychologii społecznej, psychoanalizy, filozofii i socjologii. Z bogatej literatury przedmiotu warto w tym miejscu przywołać chociażby: Spoteczne ramy pamięci Maurice'a Halbwachsa; Pamięć, historia, zapomnienie Paula Ricoeura czy Jak spoteczeństwa pamiętają Paula Connertona. Szerokie spektrum zagadnień dotyczących problemu pamięci w kontekście kulturowych uwarunkowań przedstawiają prace: Kultura jako pamięć. Posttradycjonalne znaczenie przesztości, red. E. Hałas, Kraków 2012; Memory. Histories, Theories, Debates, red. S. Radstone, B. Schwarz, New York 2010 oraz Acts of Memory. Cultural Recall in the Present, red. M. Bal, J. Crewe, L. Spitzer, Lebanon 1998. 
doświadczeniu zawiera się i znosi zawsze obce doświadczenie, przekazywane przez pokolenia czy instytucje ${ }^{7}$. Doświadczenie - w szerokim rozumieniu - oznacza proces podmiotowego przeżywania zdarzeń, którego istotną część stanowi pamięć. Przeżywanie aktualnych wydarzeń, pozostając w relacji z tym, co minione, ukazuje, w jaki sposób przeszłość jest obecna w teraźniejszości. Pamięć przywołuje przeszłość i zespala ją z teraźniejszością. Dotyka tego, co było, ale czego już nie ma, dlatego zawsze jest uobecnioną nieobecnością ${ }^{8}$. Interpretacja wydarzeń z przeszłości dokonywana jest z określonej perspektywy postrzegania i doświadczania świata oraz posiada temporalne przyporządkowanie. W tym kontekście warto postawić pytanie o charakter uwarunkowań sposobu zapamiętania wydarzeń z przeszłości oraz procesu ich odczytywania. Pamiętanie jest procesem przygodnym, personalnie i kontekstualnie określonym, nie daje się zatem wstawić w żadne ramy jednoznacznych, zobiektywizowanych definicji. Indeksykalny charakter pamięci, podobnie jak doświadczenia, określa osobowe i sytuacyjne zapośredniczenie tworzonych obrazów przeszłości'. Idea pamięci indywidualnej domaga się jednakże społecznego umocowania, ponieważ doświadczanie przesztości spetnia się w swoistym zwiazku pamiętania $i$ zapominania wspótkonstytuującym tożsamość kultur $i$ żyjacych $w$ nich ludzi $i^{10}$. To, co zapamiętane, wspominane i pielęgnowane jako pamięć własna, uwarunkowane jest obrazem przeszłości i posiada historycznie określone, społeczne ramy ${ }^{11}$. Pamiętamy jako ludzie o określonej tożsamości i przynależności grupowej. Na kształt indywidualnej pamięci decydujący wpływ wywiera uczestnictwo w grupach pokrewieństwa oraz grupach odniesienia. Dostarczają one jednostkom ram, w których obrębie wspomnienia zostaja zlokalizowane, a dzieje się to za pomoca mapowania. Sytuujemy to, co sobie przypominamy, w ramach umystowych przestrzeni dostarczanych przez grupe ${ }^{12}$.

\section{TRAJEKTORIA CIERPIENIA}

Termin „trajektoria” wprowadzony do teoretycznego języka socjologii uzyskał swoiste znaczenie, które odbiega od tego, jak rozumiany jest w fizyce, astronomii czy też w języku potocznym. W socjologii zorientowanej biograficznie trajektoria jest rozumiana jako proces biograficzny, który cechuje się zasadą doznawania stanowiącą odwrotność intencjonalności działania. Jeżeli jednostce, dzięki wykonanej pracy biograficznej, udaje się redefiniować swoją tożsamość, możemy wówczas mówić o przezwyciężeniu trajektorii. Obraz indywidualnych i zbiorowych doświadczeń, rozumianych jako świat

\footnotetext{
R. Koselleck, Semantyka historyczna, przeł. W. Kunicki, Poznań 2001, s. 365.

P. Ricoeur, Drogi rozpoznania..., s. 116.

9 F. Ankersmit, Pamiętając Holocaust: żatoba i melancholia, przeł. A. Ajschtet, A. Kubis, J. Regulska, [w:] Pamięć, etyka i historia, red. E. Domańska, Poznań 2002, s. 166.

10 D. Wolska, Odzyskać doświadczenie..., s. 77.

11 Por. M. Halbwachs, Spoteczne ramy pamięci, przeł. M. Król, Warszawa 1969.

12 P. Connerton, Jak spoteczeństwa pamiętają, przeł. M. Napiórkowski, Warszawa 2012, s. 88.
} 
przeżywany, może przybrać mniej lub bardziej uporządkowaną postać. W sytuacjach skrajnych, takich jak wojna i unicestwienie, rozpoznawane dotychczas formy porządku społecznego mogą nagle i nieubłaganie lec w gruzach. Rzeczywistość jawi się wówczas jako chaotyczna i nieprzewidywalna. Dramatyczne załamanie społecznego ładu oraz związanych z nim oczekiwań skutkuje cierpieniem i podważa zdolność działania. Cierpienie, podstawowy aspekt ludzkiej egzystencji, zostało dosyć późno włączone do naukowych rozważań i wciąż pozostaje nie w pełni docenianą kategorią socjologicznych analiz. W latach 70. XX wieku w ramach socjologii zorientowanej interakcjonistycznie zostały podjęte badania nad cierpieniem w kontekście doświadczenia choroby i umierania. Wtedy też do uchwycenia procesów cierpienia związanego z umieraniem został wykorzystany termin „trajektoria” ${ }^{13}$. Fenomen trajektorii odsłania społeczny proces powstawania chaosu i zagrożenia w życiu tak jednostek, jak i całych społeczeństw. Stan trajektorii oznacza rozpad norm moralnych i bezładne procesy społeczne, które wywołują cierpienie. Tak rozumiane pojęcie trajektorii odnosi się do badania procesów nieuporzadkowanych, nieustrukturowanych, chaotycznych, a jednocześnie przysparzajacych uczestniczacym w nich osobom cierpienia i bólu, niosacych ze soba rozpacz, poczucie nieszczęścia i kleski, wyzwalających szok i prowadzacych do zatamania. W tym więc ujęciu trajektoria zawsze dotyka cierpienia i użyta być może jako swego rodzaju metodologiczna pomoc w opisywaniu i badaniu radzenia sobie z cierpieniem ${ }^{14}$. Wprowadzenie pojęcia trajektorii miało na celu lepsze zbadanie i zrozumienie cierpienia, które powstaje i narasta w sytuacji społecznej entropii. Socjologiczna analiza procesów cierpienia wzbogaca postrzeganie rzeczywistości, albowiem koncepcja trajektorii wskazuje na to, że rzeczywistość spotecznq należy rozpatrywać nie tylko w aspekcie nadawania dziataniom struktury, lecz

13 Pojęcie trajektorii zostało wprowadzone do socjologii pod koniec lat 70. XX wieku przez amerykańskich uczonych Barney’a Glasera i Anselma Straussa w celu opisania i lepszego zrozumienia procesów umierania. Zob. B.G. Glaser, A.L. Strauss, Time for Dying, Chicago 1968; A.L. Strauss, B.G. Glaser, Anguish: The Case Study of a Dying Trajectory, Mill Valley 1970. W kolejnych latach koncepcja trajektorii została rozszerzona przez Gerharda Riemanna i Fritza Schütze, którzy wskazali na możliwość zastosowania tego pojęcia także w innych kontekstach społecznych. Ich zdaniem analiza fenomenu trajektorii posiada kluczowe znaczenie dla rozwoju teorii socjologicznej, ponieważ pozwala na zrekonstruowanie społecznych procesów powstawania bezładu i powiązanego z nim cierpienia. Schütze definiuje pojęcie trajektorii jako odwrotność kategorii biograficznego schematu działania. Silnie akcentując potrzebę badania rzeczywistości jako procesu, twierdzi, że podstawowe struktury rzeczywistości społecznej bazują na porządku sekwencyjnym. Prowadzi to do przyjęcia przez niego perspektywy biograficznej, w której przebieg życia jednostki jest analizowany za pomocą sekwencji struktur procesowych, na ogół obecnych w każdej biografii. Uznając za podstawę teorii rozróżnienie pomiędzy działaniem a doznawaniem, Schütze wyróżnia w biografii cztery struktury procesowe: biograficzne plany działania, instytucjonalne wzorce przebiegu życia, trajektorie oraz przemiany tożsamości. Potencjalne kombinacje struktur procesowych umożliwiają analizowanie biograficznych losów jednostki. Celem sekwencyjnej analizy biograficznej jest poznanie okoliczności i społecznych procesów, które nadają sens życiu jednostek. Zob. G. Riemann, F. Schütze, „Trajektoria” jako podstawowa koncepcja teoretyczna w analizach cierpienia i beztadnych procesów spotecznych, przeł. Z. Bokszański, A. Piotrowski, „Kultura i Społeczeństwo" 1992, t. 36, nr 2, s. 89-109.

14 E. Zakrzewska-Manterys, Down i zespót wątpliwości. Studium z socjologii cierpienia, Warszawa 1995, s. 17-18. 
także w aspekcie chaotycznych potencjatów pozbawiania dziatań struktury oraz dynamiki i mechanizmów rozwijania się dtugotrwatego cierpienia ${ }^{15}$.

Trajektoria odnosi się do procesów dotkliwego doświadczania cierpienia, które cechuje poczucie chaosu, przymusu, utraty kontroli oraz bezradność. Biograficzna trajektoria cierpienia rozwija się sukcesywnie, począwszy od pojawienia się przytłaczających i niepożądanych wydarzeń oraz uczucia zależności od zewnętrznych sił, swoistego fatum decydującego o losie jednostki, poprzez utracenie zdolności do intencjonalnego działania, aż po załamanie się orientacji wobec samego siebie i destabilizację rutyny codziennego życia. Jej centralnym punktem jest przekroczenie granicy pomiędzy poczynaniami o charakterze intencjonalnym a poczynaniami uwarunkowanymi. Jednostka uświadamia sobie, że nie jest już w stanie ksztattować swego życia poprzez aktywne schematy dziatania, lecz jedynie reagować w sposób uwarunkowany ${ }^{16}$. Oznacza to niemożność sprzeciwienia się temu, co rani i prowadzi do przyjęcia postawy bierności. Następuje zniesienie zdolności intencjonalnego działania na rzecz doznawania, biernego reagowania na zewnętrzne uwarunkowania. Cierpienie zrodzone przez działanie przemożnych sił zewnętrznych potrafi całkowicie zniweczyć życiowe plany i możliwości działania, a zniewalając umysł, odbiera jednostce autonomię i zaufanie do świata. W konsekwencji trajektoryjne procesy cierpienia nie tylko dezorganizują przebieg i sposób życia, ale istotnie odmieniają obraz własnej osoby i wywołują kryzys tożsamości ${ }^{17}$.

Proces konstruowania tożsamości jest głęboko osadzony w biograficznych schematach postrzegania świata i odpowiadających im wzorcach działania ${ }^{18}$. Poczucie ciągłości jaźni stanowi konstytutywną przesłankę tożsamości osobistej, która w historii życia ulega przemianom. Formowanie tożsamości dokonuje się w ciągle na nowo podejmowanych procesach samookreślania, przywoływania obrazów z przeszłości, porównywania i redefiniowania siebie. Ten swoisty dialog wewnętrzny ukazuje, jak społeczno-kulturowy kontekst i narzucone przez niego obiektywne okoliczności konfrontowane są z subiektywnymi wyobrażeniami i dążeniami ${ }^{19}$. Doświadczanie cierpienia z istoty swej jest silnie powiązane z tożsamością. Odczuwanie dotkliwego cierpienia określa - tak w wymiarze biograficznym, jak i społecznym - możliwe do przyjęcia strategie życia oraz wpływa na sposób postrzegania siebie i innych. Zamęt wywołany przez narastanie

15 F. Schütze, Trajektorie cierpienia jako przedmiot badań socjologii interpretatywnej, przeł. M. Czyżewski, „Studia Socjologiczne” 1997, nr 1, s. 46.

16 A. Rokuszewska-Pawełek, Chaos i przymus. Trajektorie wojenne Polaków - analiza biograficzna, Łódź 2002, s. 80.

17 Por. M. Melchior, Zagtada a tożsamość. Polscy Żydzi ocaleni „na aryjskich papierach”. Analiza doświadczenia biograficznego, Warszawa 2004; A. Rokuszewska-Pawełek, Druga wojna światowa - pamięć i tożsamość, „Kultura i Społeczeństwo” 2001, nr 3-4, s. 167-179.

18 Problematyka tożsamości została w ostatnich latach wielorako omówiona w literaturze przedmiotu. W odniesieniu do podejmowanych w artykule zagadnień na szczególną uwagę zasługują następujące prace: P. Ricoeur, O sobie samym jako innym, przeł. B. Chełstowski, Warszawa 2003; Ch. Taylor, Źródta podmiotowości. Narodziny tożsamości nowoczesnej, przeł. M. Gruszczyński i in., Warszawa 2001; A.L. Strauss, Zwierciadta i maski. W poszukiwaniu tożsamości, przeł. A. Hałas, Kraków 2013; K. Rosner, Narracja, tożsamość i czas, Kraków 2003.

19 Por. M. Archer, Cztowieczeństwo. Problem sprawstwa, przel. A. Dziuban, Kraków 2013. 
trajektorii paraliżuje i ogranicza sferę działań, nie poddaje się także artykulacji i zrozumieniu. Doznawanie cierpienia, boleśnie konfrontując posiadany obraz własnej osoby z rzeczywistością, prowadzi do odczucia stawania się obcym samemu sobie i próby zbadania tego wtasnego obcego wewnętrznego terytorium. Takie dtugotrwate uczucie wyobcowania się z samego siebie popycha ku dramatycznym zmianom określenia osobowej tożsamości ${ }^{20}$. Biograficznie wyznaczona trajektoria cierpienia wyzwala refleksyjność, co z czasem owocuje zmianą tożsamości. Metamorfoza spowodowana procesami trajektoryjnymi oznacza przymus porzucenia dobrze znanego wizerunku siebie na rzecz nowej tożsamości. Człowiek staje wobec utraty swojej dotychczasowej tożsamości i konieczności zbudowania nowej. Nowa tożsamość stanowi efekt przepracowania trajektorii cierpienia lub też pozostaje symptomem ustawicznego borykania się z nią. Przytłaczająca i niezrozumiała sytuacja życiowa wymusza wytworzenie odmiennych strategii radzenia sobie z codziennymi sprawami oraz redefiniowanie siebie w kontekście biograficznym. Jednostka musi stawić czoła nowej, niechcianej sytuacji i radykalnie zmienić myślenie o sobie samej. Refleksja nad tym, co się wydarzyło, i redefinicja biografii może sprzyjać tworzeniu nowych schematów działania pozwalających na przezwyciężenie trajektorii lub pozbawić jednostkę moralnej odwagi życia ${ }^{21}$. Przeżycie Zagłady jako doświadczenie graniczne, w którym życie splotło się ze śmiercią, przekreśla adekwatność dawnych autoidentyfikacji i powołuje do życia nową tożsamość, sygnowaną jako ocaleni. Przeszłość, która była bolesnym doświadczeniem rodziców, zostaje potem przekazana ich dzieciom, stając się świadectwem okrutnych czasów. Narracja o przeszłości, stanowiąc akt performatywny, posiada moc tworzenia tożsamości zarówno rodziców, jak i dzieci.

\section{TRAUMA I POSTPAMIĘĆ}

Doświadczenie Holokaustu jest stale obecne w pamięci jednostkowej i społecznej ${ }^{22}$. Pamięć społeczna rozlicza i ostrzega, a biograficzna nadal przypomina, że w swej śmiercionośnej i destrukcyjnej sile zrodziło ono haniebne żniwo, pozostawiając trwałe piętno w ludzkiej psychice. Dla pokolenia, które osobiście doznało okrucieństw wojny, wspomnienie tych doświadczeń i związane z tym emocje wciąż na nowo otwierają do tej pory niezabliźnione rany. Tragiczne wydarzenia i nieszczęścia, które były udziałem osób z tego pokolenia, wyzwoliły przeżywanie traumy ${ }^{23}$. Trauma, stanowiąc psychiczne

20 G. Riemann, F. Schütze, „Trajektoria” jako podstawowa koncepcja teoretyczna w analizach cierpienia i beztadnych procesów spotecznych, „Kultura i Społeczeństwo” 1992, nr 2, s. 98.

21 Tamże, s. 106.

22 Zob. A. Kuchta, Zawtaszczone narracje. Obrazy postpamięci w zbiorze „Oskarżam Auschwitz. Opowieści rodzinne” Mikotaja Grynberga, „Konteksty Kultury” 2015, t. 12, nr 2.

23 Pojęcie traumy, początkowo wykorzystywane głównie w medycynie i psychiatrii, znajduje obecnie szerokie zastosowanie także w analizach procesów historycznych i społecznych. Por. D. LaCapra, Historia w okresie przejściowym...; J.C. Alexander, Trauma. A Social Theory, Cambridge 2012; P. Sztompka, Trauma wielkiej zmiany. Spoteczne koszty transformacji, Warszawa 2000. W ujęciu medycznym, 
zranienie, podobnie jak procesy trajektoryjne, żywi się cierpieniem. Cierpienie, które niesie za sobą doświadczenie Zagłady, jawi się tyleż jako niewyobrażalne i nie do zniesienia, ileż niedające się wypowiedzieć24 ${ }^{24}$ Traumatyczne doświadczenie, choć tak często nie pozwala się wyrazić słowami, pozostaje głęboko osadzone nie tylko w osobniczej jaźni, ale i w ciele. I jako takie ulega pokoleniowej transmisji. Staje się wtórną pamięcią o cudzym doświadczeniu, zawłaszczonym przeżywaniem ${ }^{25}$. Rodzinna transmisja traumy wtapia się w rutynę codzienności, zostaje znaturalizowana i dlatego pozostaje niewidoczna. Trauma nieobjawiana wprost, ale też nigdy niepozwalająca się całkowicie stłumić wywiera silny wpływ na więzi rodzinne i tożsamość jej członków. Cierpienie zamknięte w słowach, bądź też tuszowane milczeniem, staje się świadectwem, które pozwala odnaleźć odpowiedź na pytanie: „Kim jestem?”.

Przejmowanie cudzych wspomnień i czynienie z nich punktu odniesienia dla procesów samookreślania okazuje się brzemienne w skutkach. Pokoleniowa transmisja powojennej traumy, warunkując sposób percepcji świata, odsłania destrukcyjne mechanizmy postpamięci. Charakterystyczna dla drugiego pokolenia, silna - i często nie do końca uświadamiana - orientacja świadomości na przeszłość prowadzi do marginalizowania rzeczywistego wymiaru egzystencji. W efekcie tego przeszłość wciąga ponad miarę i kładzie się cieniem na aktualnych, dziejących się tu i teraz wydarzeniach. Wraz z mentalnym wycofaniem ku przeszłości następuje deprecjonowanie swoich przeżyć, co zwykle prowadzi do obniżenia poczucia własnej wartości. Tożsamość osób z drugiego pokolenia kształtowana jest nie tyle przez własne doświadczenia biograficzne, ile przez fakt bycia dzieckiem ocalonego.

Pojęcie postpamięci, wprowadzone do dyskursu naukowego przez Marianne Hirsch, pozwala na ukazanie pamięci tragicznych wydarzeń z perspektywy dzieci osób ocalonych z Zagłady. Temporalny i rodzinny kontekst jest tu wyraźnie podkreślony jako konstytutywny dla pamięci drugiego pokolenia. Postpamięć to swoisty sposób odczytania i uobecnienia przeszłości w aktualnych wydarzeniach, tworzony przez narracje rodzinne. W koncepcji zaproponowanej przez Hirsch postpamięć od pamięci odróżnia pokoleniowy dystans, a od historii gtęboka osobista więź. Postpamięć jest silną i bardzo szczególna forma pamięci wtaśnie dlatego, że jej relacja wobec przedmiotu czy źródta jest zapośredniczona nie poprzez wspomnienie, ale wyobraźnię i twórczośćc ${ }^{26}$. Tragiczne doświadczenia z przeszłości rodziców, opowiedziane bądź stłumione, stanowią fundamentalne uwarunkowanie sposobu, w jaki dzieci postrzegają ich historie i samych siebie. Dotkliwie odczuwana obecność przeszłości w tym, co rzeczywiste, sprawia, że ich wtasne, spóźnio-

ogólnie rzecz ujmując, trauma oznacza długotrwały, destrukcyjny proces fizjologiczny lub głęboki uraz psychiczny, do którego dochodzi pod wpływem gwałtownych, dramatycznych przeżyć. Studia nad traumą w wymiarze społecznym i kulturowym pozwoliły na rozszerzenie perspektywy badań, uzupełniając - dominujące w większości prowadzonych analiz - nastawienie psychoanalityczne o kontekst historyczny i kulturowy.

A. Ubertowska, Świadectwo, trauma, gtos. Literackie reprezentacje Holokaustu, Kraków 2007, s. 26-27.

Por. D. LaCapra, Historia w okresie przejściowym..., s. 108.

26

M. Hirsch, Żatoba i postpamięć, przeł. K. Bojarska, [w:] Teoria wiedzy o przesztości na tle wspótczesnej bumanistyki, red. E. Domańska, Poznań 2010, s. 254. 
ne historie ulegaja zniesieniu przez historie poprzedniego pokolenia uksztattowane przez doświadczenia traumatyczne, których nie sposób ani zrozumieć, ani przetworzyc ${ }^{27}$. Drugie pokolenie przyswaja sobie doświadczenia rodziców i tym samym uruchamia pamięć przeniesioną w czasie. Przeszłość zostaje wprowadzona do ich własnych narracji, a osobiste doświadczenia zdominowane przez cudze przeżycia i sposób ich zapamiętania.

Przepełniona goryczą nostalgia za tym, czego nie przeżyło się samemu, nie jest w stanie przywołać pamięci o przeszłości, ponieważ jest jedynie jej wyobrażeniem. Przypisywanie sobie traumy rodziców i postrzeganie rzeczywistości przez pryzmat ich doświadczeń, choć autentyczne i boleśnie odczuwane, stanowi co najwyżej pośrednią i wycinkową pamięć drugiego pokolenia. Postpamięć winna być zatem postrzegana nie jako forma dokumentowania przeszłości w oparciu o pracę pamięci, ale jako twórcze jej przetworzenie. W tym kontekście Hirsch stawia pytanie o to, czym są fotografie ukazujące Zagładę. Dokonując analizy kontrowersyjnego komiksu Arta Spiegelmana, zatytułowanego Maus, Hirsch uznaje fotografie obrazujące wydarzenia z przeszłości za specyficzne miejsca pamięci (lieux de mémoire) ${ }^{28}$, które, oscylując między życiem a śmiercią, łączą przeszłość z teraźniejszością 29 . Takie ujęcie, które pozwala na zespolenie w fotografii tego, co wizualne, z tym, co werbalne, odsyła wprost do pamięci. Fotografia jako połączenie obrazu i narracji stanowi medium umożliwiające pokoleniową transmisję doświadczenia. Fotografie, posiadając moc wskrzeszania wydarzeń z przeszłości, są bardzo szczególnymi instrumentami pamięci, ponieważ ulokowaty się na krawędzi między pamięcia a postpamięcią ${ }^{30}$.

Postpamięć przywołująca przeszłość na podstawie fotografii, wydobywa z niej to, co bezpowrotnie utracone, ale ożywia również pewną dozę nieokreśloności wynikającą z upływu czasu i sposobu jej odczytania. W akcie odczytywania przeszłości świadectwo czasu minionego spotyka się z zatroskaniem dnia dzisiejszego. Artystyczny projekt Arta Spiegelmana przedstawiający historię ocalenia jego ojca skleja opowieść ocalonego z postpamięciową narracją, w której doświadczenie ojca zostaje zrównane z traumą syna. Nie chodzi bowiem o wierne zrekonstruowanie obrazu przeszłości, ale o zilustrowanie procesu konstruowania tożsamości naznaczonej traumą, ukazania siebie jako konstrukcje wizualna, która jest w stanie wydobyć napięcie między tym, co estetyczne i dokumentalne $^{31}$. Dzięki zniwelowaniu wyraźnej różnicy pomiędzy dokumentalną formą świadectwa a jego estetycznym wyrażeniem widzimy przeszłość nie tylko inaczej, ale i pełniej. W tym celu Spiegelman zastępuje fotografię dokumentalną komiksem, różnicuje treść wypowiedzi oraz formę jej przedstawiania - wszystko po to, by uchwycić życie i śmierć w symbiozie, zatrzeć granicę pomiędzy przeszłym a obecnym. Oddalenie od realności ku artystycznej fikcji pozwala postpamięci przekroczyć okrucieństwo życia w procesie twórczości. Estetyzacja doświadczenia stanowi zatem przede wszystkim

\section{Tamże, s. 254.}

28 Hirsch określa status fotografii, nawiązując do koncepcji „miejsc pamięci” opracowanej przez Pierre’a Norę. Por. P. Nora, Les lieux de mémoire, Paris 1984-1992.

30 Tamże, s. 254.

$31 \quad$ Tamże, s. 260. 
antidotum na melancholię i odczuwane cierpienie. To, czego nie można ani wypowiedzieć, ani zrozumieć, z oporem poddaje się historycznej faktografii czy naukowej eksplikacji. Albowiem to nie wyjaśnienie rzeczywistości jest tu konieczne i stosowne, lecz danie świadectwa.

\section{KONKLUZJA}

Próba opisu i zrozumienia przeszłości, dokonana może być jedynie na podstawie relacji, o tym, co się wydarzyło. Odtworzenie minionych zdarzeń, przedstawienie wiarygodnego ich opisu i wyjaśnienia stanowi cel poznania naukowego. Zabieg ten wymaga odwołania się do istniejących świadectw, różnorodnych form pamięci o przeszłości. Podstawowe ograniczenie tych starań jest natury epistemologicznej i sprowadza się do pytania o to, w jakim stopniu rzeczywiste doświadczenie daje się uchwycić w narracji. Dotarcie do prawdy o Holokauście postrzegane jest często jako niemożliwe ${ }^{32}$, zarówno dlatego, że nie istnieje jedna prawda o tym, co się wydarzyło, jak i z powodu niespójności i różnorodności dostępnych świadectw. Czynienie nieobecnego obecnym poprzez ponowne przywołanie do życia minionych zdarzeń w procesie przypominania odsłania zarówno poznawczy, jak i etyczny aspekt odczytywania przeszłości. Opis Zagłady ze względu na ogrom i nieludzki charakter zła, jakie się dokonało, uznawany jest za niewyobrażalny i z trudem znajduje moralne uzasadnienie.

Przeżycie wojny jako doznanie graniczne może stanowić źródło trajektorii tak jednostkowej, jak i zbiorowej. Dotkliwe cierpienie spowodowane wojennym chaosem i sytuacją bezustannego zagrożenia życia uruchamia procesy trajektoryjne, które dezorganizują życiowe położenie jednostki i jej tożsamość. Głębia doznanego cierpienia domaga się biograficznego przepracowania. Jedną ze strategii radzenia sobie z doświadczeniem osobistej trajektorii jest refleksyjne przepracowywanie bolesnych przeżyć w narracji przywołującej obrazy z przeszłości, chociaż paradoksalnie retrospekcja czasem może przybrać formę milczenia. Postrzeganie wojennych doświadczeń jedynie jako etapu własnej biografii umożliwia wyjście ze stanu trajektorii i powrót do codzienności życia. Przezwyciężenie trajektorii dokonuje się zatem poprzez autorefleksyjność, swoisty przymus redefiniowania siebie. Opowiadanie przeżytych wydarzeń jako biograficzna praca nad trajektorią stanowi połączenie perspektywy przeszłości z teraźniejszością, które pozwala na nadanie sensu swoim doświadczeniom i prowadzi do metamorfozy tożsamości. Pamięć nie tyle odtwarza przeszłość, ile stanowi próbę jej interpretacji z perspektywy dnia dzisiejszego. Narracja o przeszłości nie służy bowiem rekonstrukcji wydarzeń, jest raczej przetwarzaniem doświadczenia w świadectwo, które zagłusza traumę i pozwala na zbudowanie nowej tożsamości. Cierpienie ma charakter jednostkowy, ale procesy trajektoryjne i towarzysząca im trauma promieniują na

32 F. Ankersmit, Język a doświadczenie historyczne, przel. S. Sikora, „Konteksty. Polska Sztuka Ludowa” 1997, nr 1-2, s. 84-86. Zob. także: A. Maksimowska, Kryzys reprezentacji. O niemożliwym przedstawieniu rzeczywistości i urzeczywistnionych przedstawieniach, [w:] Antropolog wobec wspótczesności, red. A. Malewska-Szałygin, M. Radkowska-Walkowicz, Warszawa 2010. 
otoczenie, szczególnie dotykając najbliższych. W konsekwencji trauma, która towarzyszy biograficznej pracy nad trajektorią, jest udziałem nie tylko rodziców, ale i ich dzieci.

Traumatyczne przejścia rodziców, ich subiektywne odczucia, gdy zostaną wyartykułowane, stają się - jako doświadczenie wtórne - tworzywem tożsamości następnego pokolenia. Dzieci osób ocalonych z wojennej pożogi, chociaż osobiście nie doświadczyły Zagłady, przejmują i „usynawiają” historie rodziców wraz z towarzyszącą im traumą. Odziedziczona trauma stanowi biograficzny punkt odniesienia dla potomków ocalonych, wywierając realny, zniewalający wpływ na ich życie. Doświadczenia rodziców zostają osadzone w pamięci dzieci i przywoływane są jako własne. W konsekwencji tego pokoleniowo przekazywana trauma prowadzi do autostygmatyzacji, istotnie zakłócając procesy tożsamościowe. Zneutralizowanie negatywnej siły traumy występującej w drugim pokoleniu i zablokowanie procesów transmisji zapośredniczonej pamięci może być osiągnięte $\mathrm{w}$ twórczym przetworzeniu obrazu przeszłości. Literatura powojenna dostarcza licznych tego przykładów ${ }^{33}$. Postpamięć jako wyobrażona pamięć przeszłości to szczególna forma pamięci, która zasadza się na emocjach i otwarcie odwołuje do wyobraźni i twórczości. Literacka narracja o tym, co doświadczone - czy, patrząc szerzej, artystyczne działanie w każdej postaci - jest aktem twórczym, który stanowi próbę uchwycenia w języku tego, co - z istoty swej - nie pozwala się w pełni uchwycić. Próba zrozumienia traumy zawsze pozostaje w jakieś relacji wobec mowy. Można powiedzieć, że symptomy traumatyczne, takie jak nagte retrospekcje czy przywrócenia, moga stanowić próby zaświadczenia o prawdzie, która nie jest dostępna czy możliwa do wyartykutowania w jezzyku świadomości. A zatem trauma zaktócataby język świadomości i domagata sięjezyka innego rodzaju ${ }^{34}$. Trauma jest doświadczeniem dopominającym się o własny język, któremu literatura dostarcza językowych figur pozwalających nazwać niepojmowalną rzeczywistość. Twórczość otwiera przestrzeń, w której traumatyczne doświadczenia mogą zostać przedstawione. W postawę postmemorialną wpisane jest także moralne zobowiązanie do pamiętania i dawania świadectwa. Przedstawianie rzeczywistości w sztuce jako jej artystyczne świadectwo, które dokonuje się poza historią i etyką ${ }^{35}$, zaprasza do refleksyjnego i osobistego przepracowania przeszłości.

\section{BIBLIOGRAFIA}

Acts of Memory. Cultural Recall in the Present, red. M. Bal, J. Crewe, L. Spitzer, Lebanon 1998. Alexander J.C., Trauma. A Social Theory, Cambridge 2012.

Ankersmit F., Jezzyk a doświadczenie historyczne, przeł. S. Sikora, „Konteksty. Polska Sztuka Ludowa" 1997, nr 1-2.

33 Szerokie spektrum literackich obrazów ukazujących doświadczenie traumy zawiera praca Świadectwo trauma - gtos. Literackie reprezentacje Holokaustu Aleksandry Ubertowskiej. Artystyczne reprezentacje Zagłady nie tylko na polu literackim, ale i w sztukach plastycznych prezentuje praca Zagtada. Wspótczesne problemy rozumienia i przedstawiania, red. P. Czapliński, E. Domańska, Poznań 2009.

34 K. Bojarska, Teoria traumy jako sita lektury (rozm. z C. Caruth), „Teksty Drugie” 2010, nr 6, s. 129.

35 Por. F. Ankersmit, Pamiętając Holocaust..., s. 165. 
Ankersmit F., Narracja, reprezentacja, doświadczenie. Studia z teorii historiografii, red. i wstęp E. Domańska, Kraków 2004.

Ankersmit F., Pamiętając Holocaust: żatoba i melancholia, przeł. A. Ajschtet, A. Kubis, J. Regulska, [w:] Pamięć, etyka i historia, red. E. Domańska, Poznań 2002.

Archer M., Człowieczeństwo. Problem sprawstwa, przeł. A. Dziuban, Kraków 2013.

Badura G., O obiektywności poznania socjologicznego raz jeszcze, Kraków 2015.

Bojarska K., Teoria traumy jako sita lektury (rozm. z C. Caruth), „Teksty Drugie” 2010, nr 6.

Caruth C., Doświadczenie niczyje: trauma i możliwości historii (Freud, Mojżesz i monoteizm, przeł. K. Bojarska, „Teksty Drugie” 2010, nr 6.

Connerton P., Jak spoteczeństwa pamiętaja, przeł. M. Napiórkowski, Warszawa 2012, https:// doi.org/10.31338/uw.9788323520023.

Doświadczenie, red. T. Buksiński, Poznań 2001.

Glaser B.G., Strauss A.L., Time for Dying, Chicago 1968, https://doi.org/10.1097/00000 446196812000-00048.

Halbwachs M., Spoteczne ramy pamięci, przeł. M. Król, Warszawa 1969, https://doi.org/10. 31338/uw.9788323533627

Hastrup K., Droga do antropologii. Między doświadczeniem a teorią, przeł. E. Klekot, Kraków 2008.

Hirsch M., Family Frames: Photography, Narrative and Postmemory, Cambridge 1999.

Hirsch M., Żatoba i postpamięć, przeł. K. Bojarska, [w:] Teoria wiedzy o przesztości na tle wspótczesnej humanistyki, red. E. Domańska, Poznań 2010.

Koselleck R., Semantyka historyczna, przeł. W. Kunicki, Poznań 2001.

Kuchta A., Zawtaszczone narracje. Obrazy postpamięci w zbiorze „Oskarżam Auschwitz. Opowieści rodzinne” Mikotaja Grynberga, „Konteksty Kultury” 2015, t. 12, nr 2, https://doi.org/10. 4467/23531991KK.15.016.3712.

Kultura jako pamięć. Posttradycjonalne znaczenie przesztości, red. E. Hałas, Kraków 2012.

LaCapra D., Historia w okresie przejściowym. Doświadczenie, tożsamość, teoria krytyczna, przeł. K. Bojarska, Kraków 2009.

Maksimowska A., Kryzys reprezentacji. O niemożliwym przedstawieniu rzeczywistości i urzeczywistnionych przedstawieniach, [w:] Antropolog wobec wspótczesności, red. A. Malewska-Szałygin, M. Radkowska-Walkowicz, Warszawa 2010.

Memory. Histories, Theories, Debates, red. S. Radstone, B. Schwarz, New York 2010, https://doi. org/10.26530/oapen_626982.

Nora P., Les lieux de mémoire, Paris 1984-1992.

Nycz R., Jak opisać doświadczenie, którego nie ma?, „Teksty Drugie” 2004, nr 5.

Ricoeur P., Drogi rozpoznania, przeł. J. Margański, Kraków 2004.

Ricoeur P., O sobie samym jako innym, przeł. B. Chełstowski, Warszawa 2003.

Ricoeur P., Pamięć, historia, zapomnienie, przeł. J. Margański, Kraków 2007.

Riemann G., Schütze F., „Trajektoria” jako podstawowa koncepcja teoretyczna w analizach cierpienia i beztadnych procesów spotecznych, przeł. Z. Bokszański, A. Piotrowski, „Kultura i Społeczeństwo" 1992, t. 36, nr 2.

Rokuszewska-Pawełek A., Chaos i przymus. Trajektorie wojenne Polaków - analiza biograficzna, Łódź 2002. 
Rokuszewska-Pawełek A., Druga wojna światowa - pamięć i tożsamość, „Kultura i Społeczeństwo" 2001, nr 3-4.

Rosner K., Narracja, tożsamość i czas, Kraków 2003.

Schütze F., Prozessstrukturen des Lebensablaufs, [w:] Biographie in handlungswissenschaftlicher Perspektive, red. J. Matthes, A. Pfeifenberger, M. Stosberg, Nürnberg 1981.

Schütze F., Trajektorie cierpienia jako przedmiot badań socjologii interpretatywnej, przeł. M. Czyżewski, „Studia Socjologiczne” 1997, nr 1.

Strauss A.L, Zwierciadta i maski. W poszukiwaniu tożsamości, przeł. A. Hałas, Kraków 2013.

Strauss A.L., Glaser B.G., Anguish: The Case Study of a Dying Trajectory, Mill Valley 1970.

Taylor Ch., Źródta podmiotowości. Narodziny tożsamości nowoczesnej, przeł. M. Gruszczyński $\mathrm{i}$ in., Warszawa 2001.

Turner V., Bruner E.M., Antropologia doświadczenia, przeł. E. Klekot, A. Szurek, Kraków 2011.

Ubertowska A., Praktykowanie postpamięci. Marianne Hirsch i fotograficzne widma z Czernowitz, „Teksty Drugie” 2013, nr 4.

Ubertowska A., Świadectwo, trauma, gtos. Literackie reprezentacje Holokaustu, Kraków 2007.

Wolska D., Odzyskać doświadczenie. Sporny temat humanistyki wspótczesnej, Kraków 2012.

Zagtada. Wspótczesne problemy rozumienia i przedstawiania, red. P. Czapliński, E. Domańska, Poznań 2009.

Zakrzewska-Manterys E., Down i zespót watpliwości. Studium z socjologii cierpienia, Warszawa 1995.

Dr Irena SZLACHCICOWA - adiunkt w Instytucie Socjologii Uniwersytetu Wrocławskiego. Główne obszary zainteresowań badawczych: teoria społeczna, socjologia pogranicza, metodologia badań jakościowych. Ostatnie publikacje: Konwersacja wewnętrzna a sprawstwo w perspektywie metodologii refleksyjnej, [w:] Sprawstwo. Teorie, metody, badania empiryczne w naukach spotecznych, red. A. Mrozowicki, O. Nowaczyk, I. Szlachcicowa (2013); Disappearing borders and the unbearable lightness of identity, [w:] Advances in European Borderlands Studies, red. E. Opiłowska, Z. Kurcz, J. Roose (2017); After the Relational Turn: The Problem of Social Identity, "State of Affairs” (2017); The Relational Turn in Sociology Implications for the Study of Society, Culture and Persons, E. Hałas, P. Donati (guest editors). 